DOI https://doi.org/10.18551/rjoas.2020-12.21

\title{
DEVELOPMENT OF PARTNERSHIP TOBACCO PLANTS IN SRAGEN REGENCY, INDONESIA
}

\author{
Nugroho Riadi* \\ Master's Study Program Agribusiness, Faculty of Agriculture, Sebelas Maret University, \\ Surakarta \\ Darsono, Harisudin Mohamad \\ Faculty of Agriculture, Sebelas Maret University, Surakarta, Indonesia \\ *E-mail: rinoeg79@gmail.com
}

\begin{abstract}
Sragen Regency has the potential of natural resources that support the development of the tobacco commodity agricultural sector. The existence of a partnership program, assistance from the Tobacco Excise Production Sharing Fund (TEPSF) cannot be fully utilized in the context of developing partnership tobacco plants in Sragen Regency. The purpose of this research is to analyze the strengths, weaknesses, opportunities, and threats in the development of partnerships for tobacco cultivation in Sragen Regency and to determine the right strategy to be applied in the development of partnerships for tobacco cultivation in Sragen Regency. The research was conducted in Sragen Regency in September 2019. The method used was qualitative method using the basic method of analysis descriptive research. The results of the study showed that the IFE matrix score was 2.67 and the EFE matrix was 2.57. The grand strategy matrix diagram showed the coordinate position in quadrant I so that the strategy that can be applied is the S-O strategy. The S-O strategy SWOT analysis resulted in three strategic alternatives. The strategy that can be carried out is a market penetration strategy, which is increasing the area of tobacco in the current land location by increasing tobacco outreach activities (agricultural intensification) by optimizing the role of field extension agents maximally and utilizing supporting infrastructure through TEPSF assistance. For this reason, the participation of the local government, in this case the Sragen Regency Agriculture Service, is needed in the tobacco partnership by determining the quality and selling price of tobacco and opening new access for other tobacco partnership companies.
\end{abstract}

\section{KEY WORDS}

Tobacco, partnership, Grand Strategy Matrix, SWOT, QSPM.

Tobacco is one of the plants cultivated in Indonesia which has been developing since hundreds of years ago. Tobacco is a promising plantation to be developed. According to the Law of the Republic of Indonesia No. 39 of 2014 concerning plantations, one of the important plantation commodities is tobacco which is included in certain strategic plantations. Activities that are carried out repeatedly and from generation to generation are a cultural process that develops in society. Moreover, these activities bring benefits seen from economic and income perspective of the people who cultivate tobacco. Tobacco and cigarettes are high-value products. Hence, for several countries, including Indonesia, they play a role in the national economy as a source of foreign exchange, a source of government revenue and taxes, a source of income for farmers and community employment (cigarette farming and processing) (Rachmat and Nuryanti 2009). Slightly different conditions are experienced by tobacco farmers. Tobacco farming, especially with an export orientation, is usually asepan tobacco which is used as raw material for cigars and chopped tobacco which is used as raw material for cigarettes. These products are subject to an excise tax of approximately 40 percent. This condition is very burdensome and not conducive to the development of national tobacco. In fact, this commodity is very 
prospective both as an industry which is capable of absorbing labor extensively and as a source of foreign exchange. (Saptana and Purwantini 2004).

The cigarette industry meets its raw material needs which are tobacco leaves from tobacco farmers from various provinces in Indonesia. Data from the Directorate General Estate Crops (2019) shows that in 2018 there were four central provinces that had the largest tobacco plant population in Indonesia, namely East Java, West Nusa Tenggara, Central Java and West Java. Meanwhile, other provinces of which the development is not too large are on the islands of Sumatra, Sulawesi, East Nusa Tenggara and Bali (see Figure 1). From the four central provinces, the total contribution was $94.76 \%$ to the total Indonesian tobacco production of 195,482 tons (see Table 1). This data shows that Central Java Province has a large share of the national tobacco production. In 2018, of the total area of Indonesian tobacco area of 204,509 hectares, $99.96 \%$ of them were smallholder plantations or an area of 204,425 hectares and the remaining $0.04 \%$ were large state plantations or 84 hectares. The magnitude of the dominance of smallholder plantations has made the increase or decrease in the area of smallholder plantations greatly influencing fluctuations in tobacco acreage in Indonesia.

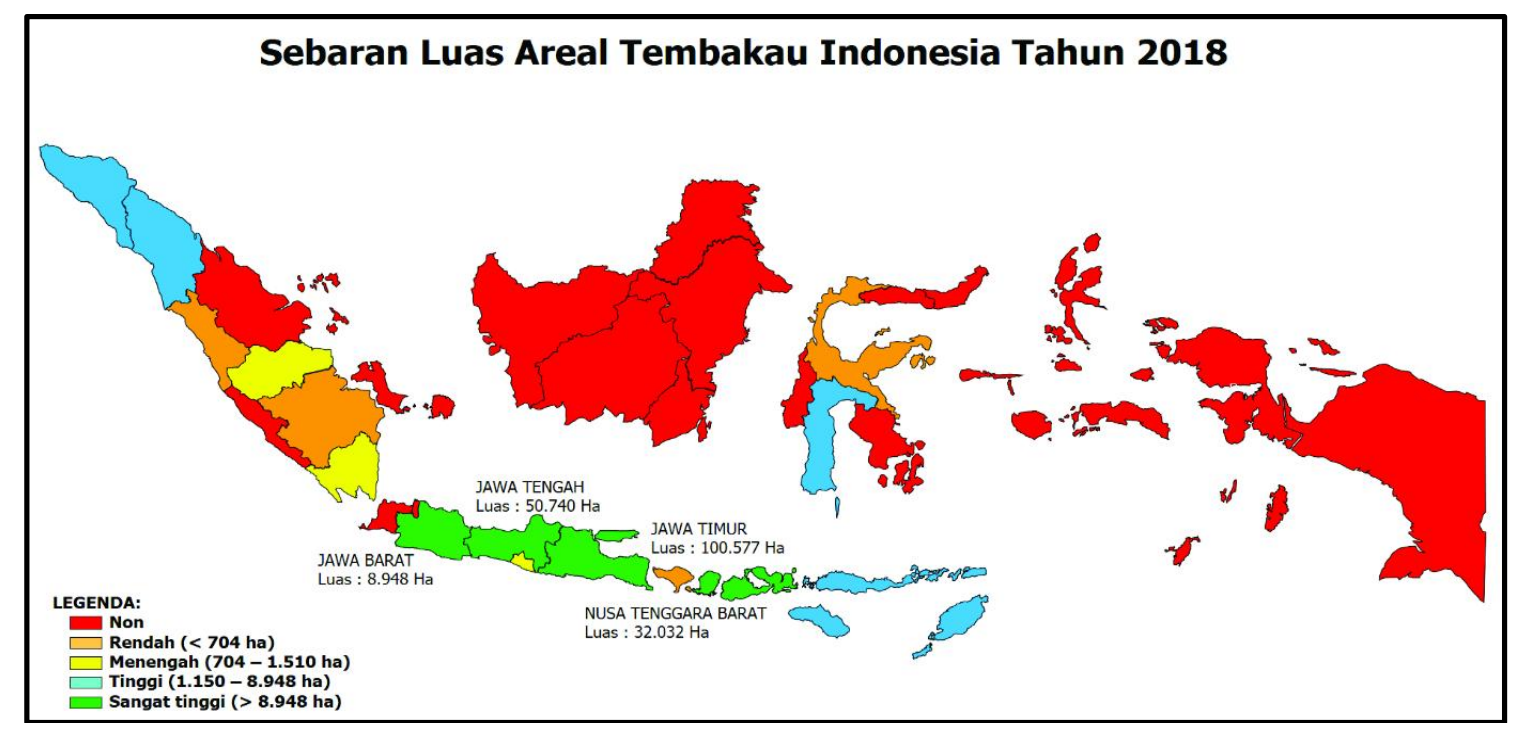

Figure 1 - Map of Tobacco Area Distribution in Indonesia, 2018

(Source: Directorate General of Estate Crops, 2019)

The fluctuation of planting area and productivity will also affect the amount of TEPSF allocation obtained by tobacco-producing regions because the fluctuation of the planted area will also affect tobacco production which is one indicator in determining the amount of TEPSF in addition to the realization of the previous year's excise revenue and the proportion of the human development index. After knowing the total amount of TEPSF it is then divided by the composition of $30 \%$ (thirty percent) for the producing province, $40 \%$ (forty percent) for the producing district / city, and 30\% (thirty percent) for other districts / cities (Indonesian Government, 2007). Tobacco in Indonesia is differentiated according to the growing season, namely Voor-Oogst tobacco and Na-Oogst tobacco. Na-Oogst tobacco is differentiated based on its physical form, namely chopped tobacco and krosok tobacco. As mentioned by Brata (2012) Even though planting the same type of tobacco in each region will produce different qualities. This is because each type of tobacco is created by soil characteristics, the level of elevation and slope of the soil, and the specific humidity in each place. The type of tobacco that is mostly cultivated by smallholders in Java, Bali, Lombok, South Sulawesi and others is chopped tobacco. It is called chopped tobacco because it is produced in chopped form and is the raw material for kretek cigarettes. Chopped tobacco is also called native tobacco, because the type of tobacco grown is 
grouped with local tobacco which is generally planted at the end of the rainy season and harvested in the dry season (Voor-oogst) (Rachmat and Nuryanti 2012).

Table 1 - Tobacco Production of Central Provinces in Indonesia, 2015-2020**)

\begin{tabular}{|c|c|c|c|c|c|c|c|c|c|}
\hline \multirow{2}{*}{ No } & \multirow{2}{*}{ Province } & \multicolumn{6}{|c|}{ Year (Ton) } & \multirow{2}{*}{$\begin{array}{l}\text { Average } \\
\text { (Ton) }\end{array}$} & \multirow{2}{*}{$\begin{array}{l}\text { Contribution } \\
(\%)\end{array}$} \\
\hline & & 2015 & 2016 & 2017 & 2018 & $\left.2019^{*}\right)$ & $\left.2020^{\star \star}\right)$ & & \\
\hline 1. & East Java & 99.743 & 42.191 & 79.442 & 84.104 & 84.524 & 84.997 & 79.167 & 99.743 \\
\hline 2. & $\begin{array}{l}\text { West Nusa } \\
\text { Tenggara }\end{array}$ & 34.449 & 39.590 & 43.971 & 45.793 & 46.031 & 46.077 & 42.652 & 34.449 \\
\hline $\begin{array}{l}3 . \\
4 . \\
5 . \\
6 . \\
7 . \\
8 .\end{array}$ & $\begin{array}{l}\text { Central Java } \\
\text { West Java } \\
\text { South Sulawesi } \\
\text { Aceh } \\
\text { North Sumatra } \\
\text { Bali }\end{array}$ & $\begin{array}{l}40.564 \\
8.471 \\
1.535 \\
1.919 \\
765 \\
1.024\end{array}$ & $\begin{array}{l}27.924 \\
8.601 \\
1.669 \\
1.626 \\
671 \\
940\end{array}$ & $\begin{array}{l}38.341 \\
8.498 \\
1.806 \\
2.017 \\
1.473 \\
1.213\end{array}$ & $\begin{array}{l}47.116 \\
8.229 \\
2.160 \\
1.734 \\
1.539 \\
1.174\end{array}$ & $\begin{array}{l}47.635 \\
8.270 \\
2.160 \\
1.889 \\
1.593 \\
1.194\end{array}$ & $\begin{array}{l}48.359 \\
8.287 \\
2.210 \\
1.933 \\
1.643 \\
1.208\end{array}$ & $\begin{array}{l}41.656 \\
8.393 \\
1.923 \\
1.85 \\
1.281 \\
1.125\end{array}$ & $\begin{array}{l}40.564 \\
8.471 \\
1.535 \\
1.919 \\
765 \\
1.024\end{array}$ \\
\hline 9. & $\begin{array}{l}\text { East Nusa } \\
\text { Tenggara }\end{array}$ & 1.324 & 967 & 1.028 & 842 & 852 & 861 & 979 & 1.324 \\
\hline $\begin{array}{l}10 . \\
11 .\end{array}$ & $\begin{array}{l}\text { D.I. Yogyakarta } \\
\text { Others }\end{array}$ & $\begin{array}{l}1.565 \\
2.432 \\
\end{array}$ & $\begin{array}{l}330 \\
2.220 \\
\end{array}$ & $\begin{array}{l}1.149 \\
2.205 \\
\end{array}$ & $\begin{array}{l}888 \\
1.903 \\
\end{array}$ & $\begin{array}{l}964 \\
2.138 \\
\end{array}$ & $\begin{array}{l}918 \\
2.247 \\
\end{array}$ & $\begin{array}{l}969 \\
2.191 \\
\end{array}$ & $\begin{array}{l}1.565 \\
2.432 \\
\end{array}$ \\
\hline & Total & 193.790 & 126.728 & 181.142 & 195.482 & 197.250 & 198.739 & 182.189 & 193.790 \\
\hline
\end{tabular}

Note: *) Temporary number; **) Estimated number. Source: Directorate General of Estate Crops (2019).

From Table 2, it can be seen that the area of tobacco in Sragen Regency fluctuates from year to year with an upward trend from the data for the last five years. In 2015, the Agriculture Service of Sragen Regency recorded that the total area of tobacco was 85 hectares, decreasing by $48.23 \%$ to 44 hectares in 2016 . The decrease in area was due to the natural phenomenon of La Nina which caused the dry season to be shorter than the rainy season which resulted many farmers tobacco experiencing crop failure. In 2017, the total area of tobacco reached $77 \mathrm{Ha}$ and increased in 2018 by $90.81 \mathrm{Ha}$. In 2019, the area of Sragen tobacco increased from the previous year of 108.37 hectares.

The potential for the development of food crop agricultural areas consists of wetland farming covering an area of $\pm 40,339$ hectares in all sub-districts of Sragen regency. Divided into irrigated rice fields with an area of approximately 25,799 hectares; non-irrigated rice fields with an area of approximately $14,540 \mathrm{Ha}$; dry land agricultural area of $\pm 24,795 \mathrm{Ha}$. Dry land food crop areas are developed for various types of crops such as; maize in almost all districts; cassava and sweet potato plants in almost all districts; tobacco plants in Sumberlawang and Mondokan Districts; coffee and clove plants in Sambirejo and Kedawung Districts; legume crops in almost all districts; melons and watermelons in almost all districts; dragon fruit plants are located in Masaran District; citrus plants in Mondokan District; longan fruit plant in Sumberlawang District (Pemerintah Daerah Kabupaten Sragen 2011).

Table 2 - The Width of Plantation Area Sub-Sector in Sragen Regency by Commodities, 2015-2019

\begin{tabular}{lllllll}
\hline \multirow{2}{*}{ No. } & \multirow{2}{*}{ Comodity } & \multicolumn{5}{l}{ Year } \\
\cline { 3 - 6 } & & 2015 & 2016 & 2017 & 2018 & 2019 \\
\hline 1. & Cane & $8.687,73$ & $7.920,62$ & $8.048,54$ & $7.935,00$ & $7.985,96$ \\
2. & Coconut & $7.962,01$ & $7.989,01$ & $8.069,10$ & $7.425,90$ & $7.086,44$ \\
3. & Cashew & $1.007,00$ & $1.007,00$ & $1.060,33$ & $1.067,33$ & $1.080,33$ \\
4. & Kapuk Randu (cotton) & 999,00 & 976,00 & 975,00 & 950,76 & 921,55 \\
5. & Clove & 313,00 & 313,00 & 363,00 & 363,00 & 461,00 \\
6. & Rubber & 63,00 & 63,00 & 63,00 & 63,04 & 63,04 \\
7. & Tobacco & 85,00 & 44,00 & 77,00 & 90,81 & 108,37 \\
8. & Kopi & 16,00 & 16,00 & 19,00 & 19,00 & 19,00 \\
\hline
\end{tabular}

Source: Sragen Regency Agriculture Office (2019).

The tobacco area in Sragen Regency is spread across 3 districts, namely Mondokan, Sumberlawang and Sukodono Districts. Tobacco grown by farmers in Sragen Regency is chopped tobacco and asepan tobacco. Based on the existing problems, this research generally aims to produce policy recommendations for the development of partnerships for 
tobacco cultivation in Sragen Regency. Specifically, the objectives of this study are (1) to identify the existing partnership patterns between tobacco farmers in Sragen Regency and Sadhana Arifnusa Ltd.; (2) identify strengths, weaknesses, opportunities and threats; (3) determine the right strategy to be implemented in developing partnerships for tobacco cultivation in Sragen Regency.

\section{METHODS OF RESEARCH}

The research location was chosen purposively (purposive sampling) in Ngargosari Village, Sumberlawang District, Sragen Regency, Central Java Province. Based on the considerations, Sumberlawang District is the district with the largest tobacco area in Sragen Regency. Ngargosari Village was chosen because it is a village of which farmer group has a tobacco partnership with Sadhana Arifnusa Ltd. This research was conducted in September 2019.

The type of data in this study is divided into two, namely primary data and secondary data. Primary data were obtained using field observations, face-to-face interviews with local communities through structured questionnaires, in-depth interviews with key informants who are the Ngargosari Village Farmers Group, chairman of the Indonesian Tobacco Farmers Association in Sragen Regency, employees of Sadhana Arifnusa Ltd., Co-Contractors and Field Assistants of Associate Contract Staff of Sragen Regency Agriculture Service, Head of Seasonal Crops Section of the Agricultural Service of Sragen Regency and Head of Plantation Division of the Sragen Regency Agriculture Service. Secondary data were obtained through literature studies of relevant books, research results and articles related to research topics from printed and electronic publications.Jenis penelitian ini merupakan penelitian kualitatif dengan menggunakan metode dasar penelitian deskriptif analisis. According to Surakhmad (2004) the characteristic of the descriptive analytical method is that it focuses on solving problems which exist in the present which are callled the actual problems. The data collected is first compiled, explained and then analyzed (therefore this method is often called the analytical method).

The research implementation technique is a case study technique. Surakhmad (2004) explains that Case studies focus on a case intensively and in detail. The subject under study consists of one unit which is seen as a case. Cases can be limited to one person, one institution, one event, one village, or a group of people and other fairly limited groups of objects that are seen as one unit.

Based on the research objectives, this study used several analytical tools in accordance with the data and information obtained. Data analysis is divided into three stages. The first stage is the identification or input stage using IFE and EFE matrix analysis to determine the strengths, weaknesses, opportunities and threats, the second stage is the matching stage with a large strategy matrix analysis and followed by a SWOT analysis. The third stage is the decision-making stage using QSPM analysis to recommend a strategy for developing partnership tobacco plants in Sragen Regency.

\section{RESULTS AND DISCUSSION}

The first stage is the Input Stage through the identification of internal and external factors in determining the priority of the partnership tobacco plant development strategy in Sragen Regency. This identification is carried out to determine what factors are the strengths and weaknesses (internal factors), as well as the opportunities and threats (external factors) that exist in the effort to develop partnerships for tobacco cultivation in Sragen Regency. Internal factors (strengths and weaknesses) and external (opportunities and threats) can describe the existing conditions in Sragen Regency, making it easier to determine the priority of the strategy to be selected through the QSPM matrix. From Table 3, it can be seen in detail what factors include in these internal and external factors.

After the internal (strengths and weaknesses) and external (opportunities and threats) factors are known, then it is created in the form of IFE and EFE matrices to see the priority 
weight of each factor. The results of weighting the IFE matrix and the EFE matrix in detail can be seen in table 4 and table 5 .

Most of the aspects in the strength factor were considered the most important by respondents to be successful in developing partnerships for tobacco cultivation in Sragen Regency. This is indicated by the largest weight $(0.40)$ in the aspect of land potential for tobacco plant development and the existence of a partnership program. The potential of the existing land and with the partnership program with Sadhana Arifnusa Ltd. becomes a strength for tobacco farmers in terms of market certainty and assurance of purchasing tobacco by Sadhana Arifnusa Ltd. The existence of this partnership program is in accordance with the research results of Kurniawan et al. (2012) which mentioned that In developing a commodity, cooperation or partnership between the private sector, government and academia is required. Mentioned by Boga Andri (2012) that to maintain the continuity of agribusiness is through good partnerships with related institutions which involve government, universities and the private sector. The smallest weighting on the strength factor is the farmers who work hard, are tenacious and diligent (0.06). This aspect is considered less important than other aspects by respondents to be successful in the development of partnership tobacco plants in Sragen Regency. Even though the farmers have the spirit of working hard, are tenacious and diligent without being supported by tobacco farming institutions and partnership programs, the development of tobacco plants will be difficult.

Table 3 - Internal and External Factors Development of Partnership Tobacco Plants in Sragen Regency, 2019

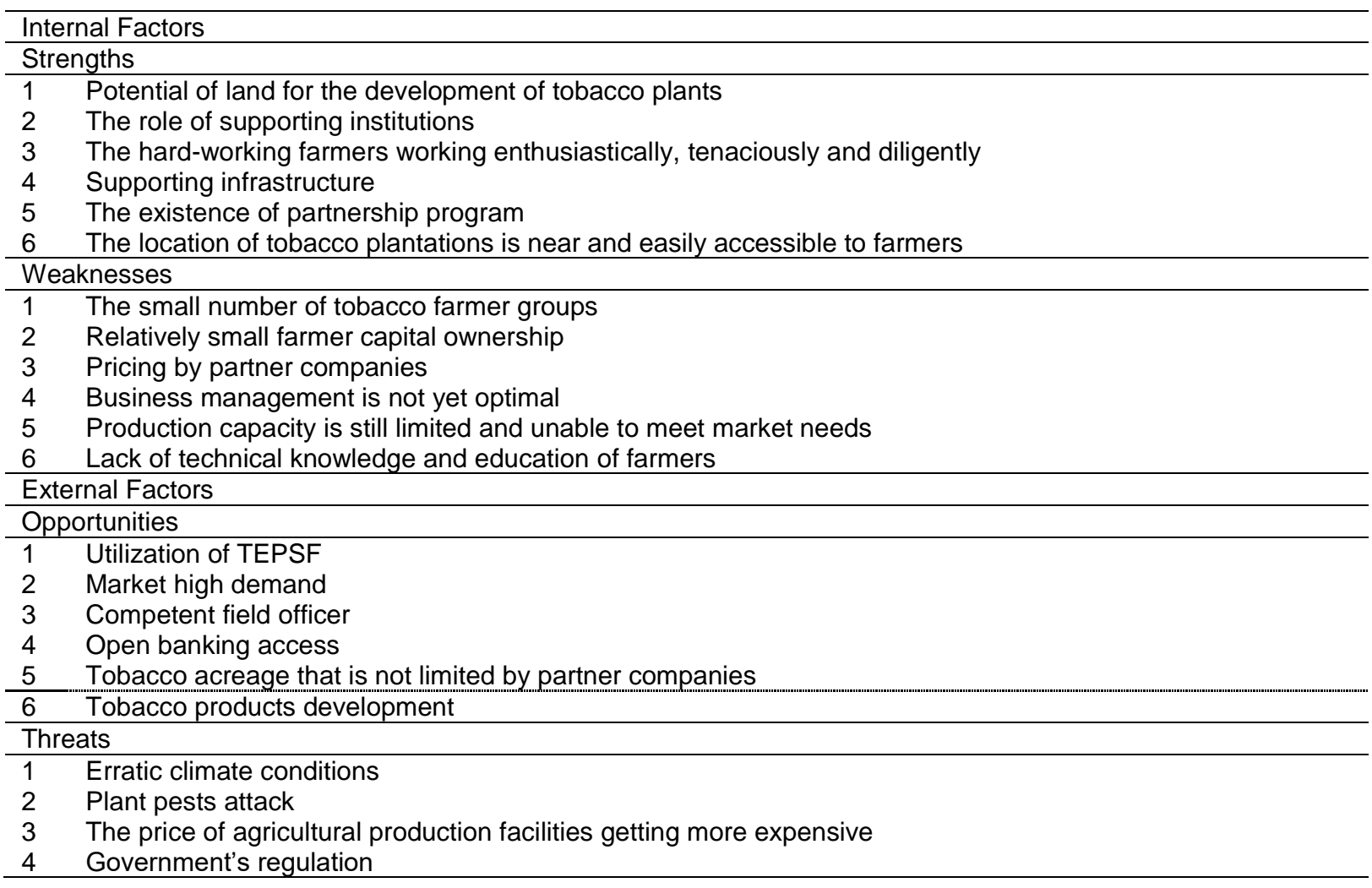

Source: Primary Data, 2019.

The biggest weight on the weakness factor is the aspect of the small number of tobacco farmer groups and the production capacity is still limited and unable to meet market needs $(0.10)$. The percentage of farmer groups makes it difficult for the local government, in this case the Department of Agriculture, to provide assistance from TEPSF funds to farmers in the form of agricultural production facilities and agricultural machinery in order to increase farmers' tobacco production. This will have an impact on the farmers' cultivation process so that the resulting production cannot be maximized. The weight of the lack of weakness 
factors is that business management is not optimal (0.06). This aspect can be accessed by respondents as an aspect that is less important than other aspects to be successful in the development of partnership tobacco plants. Business management is less important because even though there is no good management, partnership tobacco cultivation that can run smoothly states that financial records of both income and expenditure are not recorded properly.

Table 4 - IFE (Internal Factor Evaluation) Matrix Development of Partnership Tobacco Plants in Sragen Regency, 2019

\begin{tabular}{|c|c|c|c|c|}
\hline \multicolumn{2}{|c|}{ Internal Factors } & Weight & Position & Score \\
\hline \multicolumn{5}{|c|}{ Strenghts } \\
\hline 1 & The potential of land for the development of tobacco plants & 0,10 & 4 & 0,40 \\
\hline 2 & The role of supporting institutions & 0,08 & 3 & 0,24 \\
\hline 3 & The hard-working farmers working enthusiastically, tenaciously and diligently & 0,06 & 3 & 0,18 \\
\hline 4 & Supporting infrastructure & 0,08 & 3 & 0,24 \\
\hline 5 & The existence of partnership program & 0,10 & 4 & 0,40 \\
\hline 6 & The location of tobacco plantations is near and easily accessible to farmers & 0,10 & 3 & 0,30 \\
\hline \multicolumn{4}{|c|}{ Total Strength Score } & 1,75 \\
\hline \multicolumn{5}{|c|}{ Weaknesses } \\
\hline 1 & The small number of tobacco farmer groups & 0,10 & 2 & 0,20 \\
\hline 2 & Relatively small farmer capital ownership & 0,08 & 2 & 0,16 \\
\hline 3 & Pricing by partner companies & 0,08 & 2 & 0,16 \\
\hline 4 & Business management is not yet optimal & 0,06 & 1 & 0,06 \\
\hline 5 & Production capacity is still limited and unable to meet market needs & 0,10 & 2 & 0,20 \\
\hline 6 & Lack of technical knowledge and education of farmers & 0,08 & 2 & 0,16 \\
\hline \multicolumn{4}{|c|}{ Total Weaknesses Score } & 0,92 \\
\hline \multicolumn{2}{|c|}{ Internal Factor Total } & 1,00 & & 2,67 \\
\hline
\end{tabular}

Source: Primary Data, 2019.

The biggest weight on the opportunity factor is the aspect of TEPSF utilization, high market demand, competent field staff and open banking access (0.11). With the use of TEPSF, farmers can reduce the operational costs incurred mainly in the cost of fertilization because fertilizer for tobacco is quite expensive. The existence of high market demand allows farmers to increase production capacity and increase the scale of their business to meet market needs and increase profits. The smallest weighting on the opportunity factor is the development of processed tobacco products (0.04). This happens because there are still many obstacles in the development of processed tobacco products, one of which is that farmers do not have guidance or skills in the processing of tobacco products into nonsmoking products and tobacco raw materials are still limited.

The greatest weight of the threat factor is the aspect of uncertain climate conditions and the increasingly expensive price of agricultural production facilities (0.14). The production of tobacco plants is highly dependent on climatic conditions. The dry / long dry climate is very good for the development of tobacco plants. Agricultural production as well as tobacco is very dependent on four main factors, namely: plant conditions, soil conditions, climate and human or farmer intelligence (Indriani et al. 2011). According to respondents, the smallest weighting on the threat factor is government regulation (0.07). This government regulation is related to the Framework Convention on Tobacco Control (FCTC) and the Government Regulation of Republic of Indonesia Number 109/2012 concerning Safeguarding of Materials Containing Additives in the Form of Tobacco Products for Health. In the Tobacco Regulation (Article 58 paragraph 1) states that diversification is intended so that the After assessing the IFE matrix table 3 and EFE matrix table 4, it can be concluded through the matching stage (matching) through the Grand Strategy matrix to determine the relative position in the development of the Tobacco Cultivation Business Partnership in Sragen Regency. The calculation results from internal and external factors are used to determine the coordinate points of the development strategy that can be carried out. The horizontal $(X)$ axis is an internal factor. The value of the $X$ coordinate is the difference in the strength factor minus the weakness factor which is $(1.75-0.92)=0.83$. While the vertical 
axis $(Y)$ is an external factor which is the difference between the opportunity factor minus the threat factor. The value of the $Y$ coordinate is $(1.39-1.17)=0.22$. It can be seen that the results of the grand strategy matrix analysis show the coordinate position in quadrant I (one). According to David (2009), quadrant I represents companies with high market growth and a strong competitive position. In quadrant I, strategies that can be carried out are market development, market penetration, product development, forward integration, backward integration, horizontal integration and related diversification.

Table 5 - EFE (External Factor Evaluation) Matrix Development of Partnership Tobacco Plants in Sragen Regency, 2019

\begin{tabular}{|c|c|c|c|c|}
\hline \multicolumn{2}{|c|}{ External Factors } & Weight & Position & Score \\
\hline \multicolumn{5}{|c|}{ Opportunities } \\
\hline 1 & Utilization of TEPSF & 0,11 & 3 & 0,33 \\
\hline 2 & Market high demand & 0,11 & 2 & 0,22 \\
\hline 3 & Competent field officer & 0,11 & 3 & 0,33 \\
\hline 4 & Open banking access & 0,11 & 2 & 0,22 \\
\hline 5 & Tobacco acreage that is not limited by partner companies & 0,07 & 3 & 0,21 \\
\hline 6 & Tobacco products development & 0,04 & 2 & 0,08 \\
\hline \multicolumn{2}{|r|}{ Total Opportunities score } & & & 1,39 \\
\hline \multicolumn{5}{|c|}{ Threats } \\
\hline 1 & Erratic climate conditions & 0,14 & 3 & 0,42 \\
\hline 2 & Plant pests attack & 0,11 & 3 & 0,33 \\
\hline 3 & The price of agricultural production facilities getting more expensive & 0,14 & 2 & 0,28 \\
\hline & Government's regulation & 0,07 & 2 & 0,14 \\
\hline \multicolumn{3}{|c|}{ Total Threats Score } & & 1,17 \\
\hline \multicolumn{2}{|c|}{ External Factors Total } & 1,00 & & 2,57 \\
\hline
\end{tabular}

Source: Primary Data, 2019.

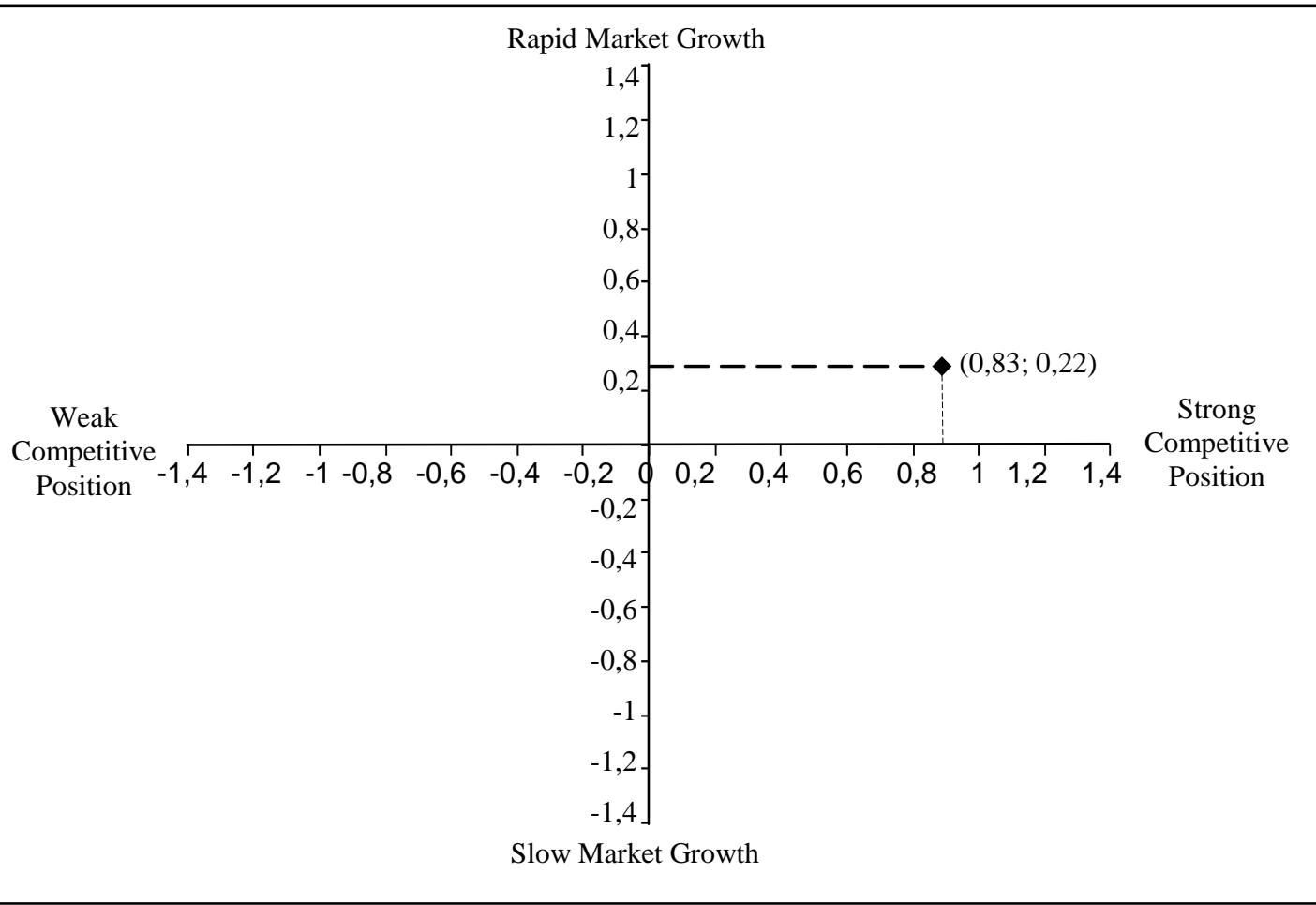

Figure 2 - Grand Strategy Matrix Development of Partnership Tobacco Plants in Sragen Regency, Indonesia 2019

The $X$ coordinate results in a value of 0.83 , which means the position of the right coordinate means a strong competitive position. The bigger the $X$ coordinate value will show the coordinate position getting more to the right so that the competitive position will also be 
stronger. The value of 0.22 in the $Y$ coordinate indicates the position of rapid market growth seen from the aspect of high market demand opportunities, the higher the coordinate point, the faster the market growth position means that the company's growth is higher. In such a position, the strategy for developing a partnership for tobacco cultivation in Sragen Regency has greater strengths than weaknesses and has greater opportunities than threats. Therefore, the right strategy to be implemented is the S-O (Strength - Opportunity) strategy by utilizing all strengths and using the greatest possible opportunities.

The next matching stage is the preparation of alternative strategies in the form of a SWOT matrix, so that several alternative strategies can be implemented for the development of partnership tobacco plants in Sragen Regency. A more complete alternative strategy can be seen in Figure 3.

Figure 3 shows an alternative strategy for S-O (Strengths - Opportunities), namely: Strategy 1: Conducting demonstration plots of tobacco plants outside the existing area. This strategy is included in the agricultural extension strategy. This strategy was chosen to increase the area of tobacco and farmer groups in a wider geographic area, not in the existing area (existing market). This strategy is not always seen in terms of geographic area, it can also be seen in terms of market segments. The old market reflects the segment where our products have been used, while the new market is intended to describe the new / untapped segment. The focus on the agricultural extension strategy referred to in this study is on the development of tobacco areas in new geographic areas. This focus is adjusted to the needs of the tobacco market which is still very open and cannot be fully fulfilled by tobacco farmers in Sragen Regency. The new geographic area is an area outside the existing area, which is outside Mondokan, Sumberlawang and Sukodono Districts. The development of new areas was carried out in other sub-districts outside the three subdistricts where there were existing tobacco areas.

Strategy 2: Providing guidance and training on the processing of tobacco products other than cigarettes. Since the enactment of Government Regulation Number. 109 of 2012 concerning Safeguarding of Materials Containing Addictive Substances in the Form of Tobacco for Health On December 24, 2012, the diversification of tobacco products began to be heavily discussed. Farmers are also starting to worry about the new government regulation because it is considered that it will kill their source of income. There are many other benefits of tobacco, including: basic chemicals that can be used as pesticides, drugs, cosmetic products (skin tighteners), the pharmaceutical industry, compost, bio-oil, fuel and others. These products are expected to be added value and have real benefits for tobacco farmers in particular and society in general. However, few researchers have pursued efforts towards diversifying non-smoking tobacco. This can be seen from the results of research on the diversification of tobacco products for non-smoking that are still very minimal. The low interest in research on the diversification of tobacco products is partly because researchers find it difficult to obtain funding (Nurnasari and Subiyakto 2019). Product diversification requires creativity, innovation, research, capital, and promotion. In addition, diversification remains market-oriented, which considers the needs, tastes, expectations, purchasing power and market segments. The government's role in supporting this strategy is to provide infrastructure, simplify licensing, rationalize official levies, and eliminate illegal levies.

Strategy 3: increasing the socialization of tobacco plants in the current location of the land. This strategy is a market penetration strategy that is better known as a strategy of sustainable agricultural intensification, through socialization with the main target of participants being members of farmer groups who have not planted tobacco. It is hoped that with the socialization, participants will be interested and willing to participate in planting tobacco so that the area of tobacco in this land location will increase. This outreach activity is a means of promotion to introduce tobacco plants more widely to farmer groups. This strategy is in accordance with research from Wahyuningsih (2016) hat one way to develop rice commodities is through the promotion of rice seed products. Socialization by optimizing the role of field extension workers and utilizing supporting infrastructure through TEPSF assistance. This strategy was chosen to increase the planted area of tobacco in certain segments and certain areas. In addition, the production TEPSF funds can be used by 
farmers to reduce high costs due to the high price of tobacco fertilizer. The high cost of fertilization will affect the benefits obtained from farmers. This influence is indicated by the factors that influence the increase and decrease in profits of Virginia tobacco agribusiness, namely the increase in the price of seeds, SP36 fertilizers and pesticides (Halil 2013).

Figure 1 - Formulation of Alternative SWOT Matrix Strategies Development of Partnership

Tobacco Plants in Sragen Regency, 2019

\begin{tabular}{|c|c|c|}
\hline & Strengths (S) & Weaknesses (W) \\
\hline & $\begin{array}{l}\text { 1. The potential of land for the development } \\
\text { of tobacco plants } \\
\text { 2. The role of supporting institutionsSarana } \\
\text { prasarana pendukung } \\
\text { 3. The Existence of Partnership Program } \\
\text { 4. Hard-working, enthusiastic, tenacious } \\
\text { and diligent farmers } \\
5 \text {. The location of tobacco plantations is } \\
\text { near and easily accessible to farmers }\end{array}$ & $\begin{array}{l}\text { 1. Lack of technical knowledge and education } \\
\text { of farmers } \\
\text { 2. The farmer's capital ownership is relatively } \\
\text { small } \\
\text { 3. Pricing by partner companies } \\
\text { 4. Business management is not optimal } \\
\text { 5. Production capacity is still limited and unable } \\
\text { to meet market needs } \\
6 \text {. The number of tobacco farmer groups is } \\
\text { small }\end{array}$ \\
\hline Opportunities (O) & Strategies S-O & Strategies W-O \\
\hline $\begin{array}{l}\text { 1. TEPSF utiliziation } \\
\text { 2. High market demand } \\
\text { 3. Competent Field Officers } \\
\text { 4. Open banking access } \\
\text { 5. Tobacco area is not } \\
\text { limited by partner companies } \\
\text { 6. Development of } \\
\text { processed tobacco products }\end{array}$ & $\begin{array}{l}\text { 1. Conducting a demonstration plot of } \\
\text { tobacco plants outside the existing area } \\
\text { (S1, O1, O5) } \\
\text { 2. Providing guidance and training on } \\
\text { processing tobacco products other than } \\
\text { cigarettes (S2, S3, S5, O3, O4, O6) } \\
\text { 3. Increasing the socialization of tobacco } \\
\text { plants in the current land location ( } \mathrm{S} 1, \mathrm{~S} 4 \text {, } \\
\mathrm{S} 6, \mathrm{O} 1, \mathrm{O} 5)\end{array}$ & $\begin{array}{l}\text { 1. Increasing capital for area development by } \\
\text { utilizing financial institutions to increase } \\
\text { production (W2, W5, O2, O4) } \\
\text { 2. Improving farmer knowledge and skills and } \\
\text { improve financial and administrative recording } \\
\text { systems in tobacco cultivation (W1, W4, W6, } \\
\text { O1, O3) } \\
\text { 3. Farmers through farmer groups establish } \\
\text { financial institutions or cooperatives (W2, W3, } \\
\text { W6, O2, O3, O5) }\end{array}$ \\
\hline Threats $(T)$ & Strategies S-T & Strategies W-T \\
\hline $\begin{array}{l}\text { 1. Erratic climatic conditions } \\
\text { 2. Government regulations } \\
\text { 3. The price of agricultural } \\
\text { production facilities is getting } \\
\text { more expensive } \\
\text { 4. Plant Pests attack }\end{array}$ & $\begin{array}{l}\text { 1. Changing the old culture and paradigm } \\
\text { of tobacco farmers by conducting initial } \\
\text { planting with the TOT system (S1, S3, S4, } \\
\text { S5, S6, T1, T4) } \\
\text { 2. Performing intensive maintenance by } \\
\text { optimizing cultivation techniques, in order to } \\
\text { avoid pest attacks (S2, T1, T5) }\end{array}$ & $\begin{array}{l}\text { 1. Using modern machine tools to reduce } \\
\text { production costs }(\mathrm{W} 6, \mathrm{~T} 3) \\
\text { 2. Developing a new mechanism on the } \\
\text { tobacco purchasing system with the role of the } \\
\text { government as a moderator between farmers } \\
\text { and partnership companies (W3, W6, T3, T4) }\end{array}$ \\
\hline
\end{tabular}

Source: Primary Data, 2019.

Strategy 3: increase the socialization of tobacco plants in the current location of the land. This strategy is a market penetration strategy that is better known as a strategy of sustainable agricultural intensification, through socialization with the main target of participants being members of farmer groups who have not planted tobacco. It is hoped that with the socialization, participants will be interested and then participate in planting tobacco so that the area of tobacco in this land location will increase. This outreach activity is a means of promotion to introduce tobacco plants more widely to farmer groups. This strategy is in accordance with research from Wahyuningsih (2016) that one way to develop rice commodities is through the promotion of rice seed products. Socialization by optimizing the role of field extension workers and utilizing supporting infrastructure through TEPSF assistance. This strategy was chosen to increase the planted area of tobacco in certain segments and certain areas. In addition, the production TEPSF funds can be used by farmers to reduce high costs due to the high price of tobacco fertilizer. The high cost of fertilization will affect the benefits obtained from farmers. This influence is indicated by the factors that influence the increase and decrease in profits of Virginia tobacco agribusiness, namely the increase in the price of seeds, SP36 fertilizers and pesticides (Halil 2013). This strategy is carried out by making the most of the supporting facilities and infrastructure. The existence of potential Natural Resources supported by adequate infrastructure will be able to produce tobacco with the expected productivity and quality. It takes the role and the maximum of all shareholders, namely farmer groups, APTI, Sragen Regency Agriculture Service, agricultural extension agents, and a partnership company Sadhana Arifnusa Ltd.

This stage is the last stage called the decision-making stage using the QSPM matrix. Strategy alternatives that will be used as input data in the QSPM matrix are obtained from 
the SWOT matrix based on the results of the big strategy matrix. The decision-making stage is the stage for determining strategic priorities for the implementation of several alternative strategies. The priority of alternative strategies is determined by looking at the level of the total attractiveness score (Total Attractiveness Score / TAS). Based on the results of QSPM analysis, the alternative strategy that has the highest total ranking is the strategic priority chosen in the development of partnership tobacco plants in Sragen Regency. Table 6 describes in detail the decision making process using the QSPM matrix.

From table 6 of the QSPM matrix, it can be explained that there are three strategies to be selected as priority strategies for the development of partnership tobacco plants in Sragen Regency. Strategy 1 is to carry out a demonstration plot of tobacco plants outside the current area (agricultural extension) with a TAS value of 5.51. The second strategy is to provide guidance and training on the processing of tobacco products other than cigarettes (tobacco product diversification) with a TAS value of 4.63. Meanwhile, the third alternative strategy is to increase the socialization of tobacco plants in the current land location (agricultural intensification) with a TAS value of 7.30 .

Strategy 1 is to carry out a demonstration plot of tobacco plants outside the current area (agricultural extension) with a TAS value of 5.51. Respondents considered that the first strategy of extensification of agriculture in new geographic areas was the second priority for the development of partnership tobacco plants in Sragen Regency. According to Hutabarat and Huseini (2006) Strategy 1 is to carry out a demonstration plot of tobacco plants outside the current area (agricultural extension) with a TAS value of 5.51. Respondents considered that the first strategy of extensification of agriculture in new geographic areas was the second priority for the development of partnership tobacco plants in Sragen Regency. According to Hutabarat and Huseini (2006) in order for the market expansion strategy to be implemented effectively, several factors need to be considered. These factors include (1) the condition of the company which is quite good, (2) the market that has not been used (not saturated), (3) the industry is increasingly global, (4) capital and human resources, (5) production capacity, and (6). ) the availability of good, reliable, and cheap distribution channels.

Strategy 2 is to provide guidance and training on the processing of tobacco products other than cigarettes (tobacco product diversification) with a TAS value of 4.63 . The tobacco product diversification strategy is the last choice because the respondents think that it is not really necessary to implement this strategy because the tobacco product diversification strategy requires new capabilities and skills, as well as new technologies that are not yet owned by tobacco farmers in Sragen Regency. Farmers are more focused on increasing their planted area and improving the quality of tobacco according to Sadhana Arifnusa Ltd.'s standards. In addition, the remaining tobacco leaves that Sadhana Arifnusa Ltd did not buy can still be sold in the public market as a cigarette mixture by the small-scale cigarette industry. The diversification strategy was not the top priority strategy chosen by the respondents to be implemented. This is because the diversification strategy is seen as a strategy with the most complex implications. This complexity is related to new experiences, both in terms of the market (new market) and in terms of products (new products). Tobacco diversification aims to obtain new products other than as raw material for cigarettes which have high economic value and are beneficial to humans. As mentioned by Rachmat and Nuryanti (2009) In the long term, it is necessary to anticipate a decrease in demand for tobacco / cigarettes by introducing alternative crops to substitute tobacco that have positive impacts on human health and the environment. The substitution implementation must be supported by all parties with an interest in the availability of market guarantees. Judging from the TAS value, from the opportunity aspect, the development of processed tobacco products shows a value of 0.11 which is the smallest among other opportunity aspects.

Strategy 3 is to increase the socialization of tobacco plants in the current land location (agricultural intensification) with a TAS value of 7.30. This strategy is one of the strategies included in the agricultural intensification strategy by increasing the area of tobacco and farmer groups in the existing sub-district. tobacco, namely in the Districts of Sumberlawang, Mondokan and Sukodono. With areas that have been planted with tobacco, it is hoped that 
people or farmers who have not planted tobacco will be interested and participate in growing tobacco. This strategy is carried out by making the most of the supporting facilities and infrastructure. The existence of natural resources potential which is supported by adequate infrastructure will be able to produce tobacco with the expected productivity and quality. Maximum participation is needed from farmer groups, APTI, the Sragen Regency Agriculture Service, agricultural extension agents, and the partnership company Sadhana Arifnusa Ltd.

The order of priority of the first strategy is the strategy of increasing the socialization of tobacco plants in the current land location (agricultural intensification) with a TAS value of 7.30 , then the second priority is the strategy of conducting a demonstration plot of tobacco plants outside the existing area (agricultural extensification) with a TAS value of 5.51, and the third place is the strategy of providing guidance and training on the processing of tobacco products other than cigarettes (tobacco product diversification) with a TAS value of 4.63. Therefore, the selected strategic priority that is suitable for the development of partnership tobacco plants in Sragen Regency is a market penetration strategy which means increasing the socialization of tobacco plants in current land locations (agricultural intensification) in a sustainable manner by increasing the total area of tobacco in the current land location, optimizing the role of field extension agents maximally by utilizing the supporting infrastructure through TEPSF assistance.

Table 6 - QSPM (Quantitative Strategic Planning Matrix) Matrix Development of Partnership Tobacco Plants in Sragen Regency, 2019

\begin{tabular}{|c|c|c|c|c|c|c|c|c|}
\hline \multirow{2}{*}{\multicolumn{2}{|c|}{$\begin{array}{l}\text { Internal Factors and } \\
\text { External Factors }\end{array}$}} & \multirow{2}{*}{ Weight } & \multicolumn{2}{|c|}{ Strategy 1} & \multicolumn{2}{|c|}{ Strategy 2} & \multicolumn{2}{|c|}{ Strategy 3} \\
\hline & & & AS & TAS & AS & TAS & AS & TAS \\
\hline \multicolumn{9}{|c|}{ Strengths } \\
\hline 1 & The potential of land for the development of tobacco plants & 0,10 & 2 & 0,20 & 3 & 0,30 & 4 & 0,40 \\
\hline 2 & The role of supporting institutions & 0,08 & 2 & 0,16 & 3 & 0,24 & 4 & 0,32 \\
\hline 3 & $\begin{array}{l}\text { The hard-working farmers working enthusiastically, tenaciously and } \\
\text { diligently }\end{array}$ & 0,06 & 3 & 0,18 & 2 & 0,12 & 4 & 0,24 \\
\hline 4 & Supporting infrastructure & 0,08 & 3 & 0,24 & 2 & 0,16 & 4 & 0,32 \\
\hline 5 & The existence of partnership program & 0,10 & 3 & 0,30 & 2 & 0,20 & 4 & 0,40 \\
\hline 6 & $\begin{array}{l}\text { The location of tobacco plantations is near and easily accessible to } \\
\text { farmers }\end{array}$ & 0,10 & 2 & 0,20 & 3 & 0,30 & 4 & 0,40 \\
\hline \multicolumn{9}{|c|}{ Weaknesses } \\
\hline 1 & The small number of tobacco farmer groups & 0,10 & 4 & 0,40 & 2 & 0,20 & 3 & 0,30 \\
\hline 2 & Relatively small farmer capital ownership & 0,08 & 3 & 0,24 & 2 & 0,16 & 4 & 0,32 \\
\hline 3 & Pricing by partner companies & 0,08 & 4 & 0,32 & 2 & 0,16 & 3 & 0,24 \\
\hline 4 & Business management is not yet optimal & 0,06 & 3 & 0,18 & 1 & 0,06 & 4 & 0,24 \\
\hline 5 & Production capacity is still limited and unable to meet market needs & 0,10 & 3 & 0,30 & 2 & 0,20 & 4 & 0,40 \\
\hline 6 & Lack of technical knowledge and education of farmers & 0,08 & 2 & 0,16 & 1 & 0,08 & 3 & 0,24 \\
\hline \multicolumn{9}{|c|}{ Opportunities } \\
\hline 1 & Utilization of TEPSF & 0,11 & 2 & 0,22 & 3 & 0,33 & 4 & 0,44 \\
\hline 2 & Market high demand & 0,11 & 2 & 0,22 & 3 & 0,33 & 4 & 0,44 \\
\hline 3 & Competent field officer & 0,11 & 2 & 0,22 & 3 & 0,33 & 4 & 0,44 \\
\hline 4 & Open banking access & 0,11 & 2 & 0,22 & 1 & 0,11 & 3 & 0,33 \\
\hline 5 & Tobacco acreage that is not limited by partner companies & 0,07 & 2 & 0,14 & 3 & 0,21 & 4 & 0,28 \\
\hline 6 & Tobacco products development & 0,04 & 2 & 0,08 & 1 & 0,04 & 3 & 0,12 \\
\hline \multicolumn{9}{|c|}{ Threats } \\
\hline 1 & Erratic climate conditions & 0,14 & 2 & 0,28 & 3 & 0,42 & 4 & 0,56 \\
\hline 2 & Plant pests attack & 0,11 & 4 & 0,44 & 2 & 0,22 & 3 & 0,33 \\
\hline 3 & The price of agricultural production facilities getting more expensive & 0,14 & 4 & 0,56 & 2 & 0,28 & 3 & 0,42 \\
\hline \multirow[t]{3}{*}{4} & Government's regulation & 0,07 & 4 & 0,28 & 3 & 0,21 & 2 & 0,14 \\
\hline & Total & & & 5,51 & & 4,63 & & 7,30 \\
\hline & Priority & & & 2 & & 3 & & 1 \\
\hline
\end{tabular}

Source: Primary Data, 2019.

\section{CONCLUSION}

Internal factors (strengths and opportunities) and external (weaknesses and threats) as an effort to develop partnership tobacco plants in Sragen Regency are as follows: Strengths: Potential land for the development of tobacco plants, roles between supporting institutions, supporting infrastructure, partnership programs, farmers are enthusiastic to work hard, are tenacious and diligent and the location of tobacco plantations is close and easy to reach by farmers; Weaknesses: The number of tobacco farmer groups is small, 
farmers' capital ownership is relatively small, pricing by partner companies, business management is not optimal, production capacity is still limited and unable to meet market needs, lack of technical knowledge and farmer education. Opportunities: Utilization of TEPSF, high market demand, competent field officers, open access to banking, tobacco acreage is not limited by partner companies, Development of processed tobacco products. Threats: Unpredictable climatic conditions, pest attacks, increasingly expensive agricultural production facilities, government regulations.

The strategy that can be carried out in the development of partnership tobacco plants in Sragen Regency is a market penetration strategy which refers to increasing the area of tobacco in the current land location by increasing tobacco socialization activities (agricultural intensification) and by optimizing the role of field extension agents, as well as maximally and utilizing supporting infrastructure TEPSF assistance.

Policy Implication. The role of the local government through the Sragen Regency Agriculture Office is needed in a partnership between Sadhana Arifnusa Ltd and tobacco farmers through determining the quality of tobacco along with the selling price that needs to be agreed at the beginning of the contract and determining the initial planting and extent of tobacco. Sadhana Arifnusa Ltd. also needs to provide data on tobacco demand at the beginning of the growing season so that the ideal tobacco partnership will be achieved. The local government has succeeded in developing tobacco acreage and increasing tobacco production, increasing farmers' welfare with sales and a certain market to Sadhana Arifnusa Ltd. Sadhana Arifnusa Ltd. obtains tobacco supplies according to the expected quality.

The Regional Government of Sragen Regency through the Agriculture Office of Sragen Regency needs to make policies related to the development of partnership tobacco plants, especially policies that support the strategy of agricultural intensification. This policy can be realized by increasing the amount of TEPSF funds allocated to help tobacco farmers so that the the amount of help for tobacco farmers can increase.

The Sragen Regency Agriculture Office can open new access related to other tobacco partnership companies to add information and as a comparison for farmer groups to determine which tobacco partnership companies are more profitable, more open to partner farmers and partner companies. Sragen Regency Agriculture Office can search for information related to tobacco partnership companies by means of field surveys / work visits to cigarette factories so that data on tobacco partnership companies that supply tobacco companies' tobacco raw materials can be obtained to establish cooperation or partnerships for tobacco farmers.

\section{REFERENCES}

1. Boga Andri K. 2012. Analisa manajemen rantai pasok agribisnis tembakau Selopuro Blitar bagi kesejahteraan petani lokal. In: Seminar Nasional Kedaulatan Pangan and Energi. Madura.

2. Brata W. 2012. Tembakau atau mati (kesaksian, kegelisahan, and harapan seorang petani tembakau). Jakarta: Indonesia Berdikari.

3. David FR. 2009. Manajemen strategis. 12 Buku 1. Wuriarti P, editor. Jakarta: Salemba Empat.

4. Dinas Pertanian Kabupaten Sragen BP. 2019. Buku Statistik Perkebunan. Sragen.

5. Direktorat Jenderal Perkebunan KP. 2019. Statistik Perkebunan Indonesia 2018-2020. https://drive.google.com/file/d/1PUZMjWPKEdPkpbUCtWo_aLi9xDVN_4TW/view.

6. Halil. 2013. Pengaruh kemitraan terhadap efisiensi tembakau Virginia di Pulau Lombok Nusa Tenggara Barat. Institut Pertanian Bogor.

7. Hutabarat J, Huseini M. 2006. Proses, formasi, and implementasi manajemen strategik kontemporer operasionalisasi strategi. Jakarta: Elex Media Komputindo.

8. Indriani O, Wiresyamsi A, Sukmawati. 2011. Penetapan pola tanam berdasarkan model Arima di Kecamatan Praya Timur Lombok Tengah. Agroteksos. 21(1):11-18.

9. Kurniawan H, Guntoro B, Wihandoyo. 2012. Strategi pengembangan ayam ras petelur di Kota Samarinda Kalimantan Timur. Bul Peternak. 35(1):57. 
doi:10.21059/buletinpeternak.v35i1.591.

10. Nurnasari E, Subiyakto S. 2019. Diversifikasi produk tembakau non rokok. Perspektif. 17(1):40. doi:10.21082/psp.v17n1.2018.40-51.

11. Pemerintah Daerah Kabupaten Sragen. 2011. Peraturan Daerah Kabupaten Sragen tentang rencana tata ruang wilayah Kabupaten Sragen 2011-2031.

12. Pemerintah Republik Indonesia. 2007. Undang-Undang Republik Indonesia Nomor 39 Tahun 2007. Indonesia.

13. Rachmat M, Nuryanti S. 2009. Dinamika agribisnis tembakau dunia and implikasinya bagi Indonesia. Forum Penelit Agro Ekon. Vol 27(No. 2):73-91. doi:http://dx.doi.org/10.21082/fae.v27n2.2009.73-91.

http://ejurnal.litbang.pertanian.go.id/index.php/fae/article/view/3923.

14. Rachmat M, Nuryanti S. 2012. Rantai pasok tembakau Indonesia. In: Lokollo EM, editor. Bunga Rampai Rantai Pasok Komoditas Pertanian Indonesia. IPB Press. p. 124-136.

15. Saptana SF, Purwantini T. 2004. Efisiensi and daya saing usahatani tebu and tembakau di Jawa Timur and Jawa Tengah. In: Prosiding: Efisiensi and Daya saing Sistem Usahatani Beberapa Komoditas Pertanian di Lahan Sawah. Pusat Peneltian and Pengembangan Sosial Ekonomi Pertanian. Bogor. http://pse.litbang.pertanian.go.id/ind/pdffiles/pros-04_2004.pdf.

16. Surakhmad W. 2004. Pengantar penelitian-penelitian ilmiah (dasar, metoda and teknik). Bandung: Tarsito.

17. Wahyuningsih T. 2016. The Development Strategy of Main Commodities of Rice in Buru District, Maluku. World J Agric Res. 4(1):9-17. doi: 10.12691/wjar-4-1-2. http://pubs.sciepub.com/wjar/4/1/2. 